\title{
Cold-Active Pectinases and their Commercial Applications: A Review
}

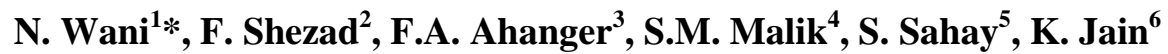 \\ 1,2,3,4,5,6 Government Science and Commerce College, Benazir, Barkatullah University, Bhopal-462 003 (MP) India \\ *Corresponding Author: Waninajeeb161@gmail.com
}

Available online at: www.isroset.org

Accepted: 24/Aug/2018, Online: 30/Aug/ 2018

\begin{abstract}
Pectinases is a group of enzymes that catalyze hydrolysis of complex pectic polysaccharides of plant tissues into simpler form, for example, galacturonic acid. They are one of the enzymes that enjoy highest market place. Food industries at large depend on this group of enzymes. Functionally, these biocatalysts are being utilized widely in different industrial procedures like liquefaction, clarification, and extraction of fruit juice in food industries including in wine making. Their importance also lies in the fact that as enzyme they participate in the process that is less aggressive and less energy demanding vis-à-vis synthetic process. Enzyme mediated processing is thus said to be eco-friendly one. Pectinases utilized currently in the food industries are mostly derived from mesophilic or thermophilic microorganisms. But, some trends towards obtaining these enzymes from cold-adapted microorganisms is also being felt. The reason for this is the recognition of the fact that cold processing saves the nutritious quality and aromatic profile of the product.
\end{abstract}

Cold-adapted microorganisms producing psychrophillic pectinases which work at low to freezing temperatures are known. Cold-active pectinases apart from being suitable for food industries for the reasons mentioned above, they are also considered to be a better alternative for various other applications like bio-refinery of pectic substances, bioremediation etc. This review describes information available on the cold-active pectinolytic enzymes, their substrates and industrial applicability of these enzymes in varied sectors.

Key words- Cold-active pectinases, Pectin, Pectinolytic enzymes, psychrophiles, industrial applications

\section{INTRODUCTION}

Cold-active catalysts are recognized by their high catalytic efficiency at low and moderate temperatures at which mesophilic enzymes are less or not active, making them fascinating for both, fundamental research and modern industrial applications. Among the most recent years extensive variety of microorganisms producing cold-active enzymes has been described. Cold-active yeasts are the most promising hotspot for application in biodegradation processes and for obtaining enzymes [41, 60]. Cold-active proteins are appealing for the food preparing, since there is a modern pattern to treat food stuffs under gentle conditions with a specific goal to stay away from decay and changes in taste and nutritious values $[59,90]$. In this manner, keenness for cold-active compounds has been expanding over the years and literatures describing their application in food industries are also growing enormously $[33,70]$.

Psychrophiles are a standout amongst the most underutilized resources and these psychrophilic and psychotropic microorganisms occupy extensive space in the colder regions on our planet having temperature in most part of the year under $5^{\circ} \mathrm{C}$. In order to keep up metabolic rates even at low temperatures, psychrophiles contain enzymes that have a higher life activity at low temperatures. These catalysts are by and large commonly named as cold-active enzymes and are thermo labile [16, 61, and 62]. For long time, those microbes having potential to develop at low temperatures have been known [37, 66]. Cold adjusted organisms can develop at $0^{\circ} \mathrm{C}$ and are psychrophilic if they love to grow between $\leq 15^{\circ} \mathrm{C}$ and $\leq 20^{\circ} \mathrm{C}$, or as psychrotrophic if their optimum temperature for growth is above $20^{\circ} \mathrm{C}$ [88]. Psychrotolerant organisms have an optimum temperature growth is near $20^{\circ} \mathrm{C}$ and $40^{\circ} \mathrm{C}$ but at the same time they are able to grow at $0^{\circ} \mathrm{C}$ [67].

Microorganisms are the vital source for the supply of a huge variety of compounds. Catalysts are the bio-active compounds that direct numerous chemical changes in living tissues. Pectins are the fluctuating structural polysaccharides in higher plants possessing elongated Galacturonic acid chains along with carboxyl group deposits and with differing level of methyl esters [54]. They are noticeably found in middle lamella and primary cell wall comprising $33 \%$ of the 
dry weight of plant tissue [102]. Pectins are the polysaccharides abundantly present in the fruits [119].

Pectinases are a enzymes associated with the breakdown of pectin from wide array of plants. These are categorized according to their favored substrate (pectin, pectic acid), the degradation action (transelimination or hydrolysis) and the kind of cleavage (random or terminal) [48, 116].

Pectinases despite of their use in different industries are specially applied in fruit processing industries as juice clearer, color and yield enhancers and in fruit pulp treatment [19]. Pectinases assume a significant part in clarification [45] handling of alcoholic beverages, extraction, in viscosity reduction, to expel off the peels and to get bigger yield [63]. The pectinases has been found to be widely and abundantly produced in bacteria and filamentous fungi [76, 110]. Aspergillus niger is the principle source of pectinases for industrial use since it produces large quantity of these catalysts and also it is a GRAS microorganism [5, 41]. The possibility of utilizing pectinases from cold-adapted yeasts for industrial purposes is a recent trend. The cold-active pectinolyic enzymes such as pectin methylesterase (PME), endo-polygalacturonase (endo-PG) and exopolygalacturonase (exo-PG) from psychrophilic yeasts Cystophilobasidium capitatum SPY11 and psychrotolerant yeast Rhodatorula mucilaginosa PT1 showed $50-80 \%$ of their optimum activity under specific set of conditions such as $\mathrm{pH} 3$ to 5 and temperature 6 to $15^{\circ} \mathrm{C}$. These features speak of their potential to be utilized in wine making and juice processing at low temperatures [37]. For extraction as well as processing of wines, such cold-active pectinolytic enzymes are highly appreciated [64]. Earlier, similar results have been reported with pectinolytic activity from psychrophilic Cystophilobasidium capitatum PPY at $5^{\circ} \mathrm{C}$ [71].

The expanding energy needs have necessitated the usage of sustainable resurces, especially agro and forest generated biomass, the main parts of which are cellulose, starch, lignin, xylan and pectin. These materials have attracted world-wide attention as an optional feedstock and energy source, since they are present in large quantity and easily accessible. A number of microorganisms are equipped for utilizing these substances as carbon and energy sources thereby producing a wide range of enzymes with unique catalytic features $[8,25]$. Because of the wide range of commercial uses of pectinases in the market, improvement of production technology, streamlining the fermentation protocols and application of novel retrieval techniques made the microbial generation of enzymes reasonable [35,43]. Reduction in the capital investment by utilizing wastes generated in agricultural and fruit processing operations on the other hand is helping in economizing the technology and reducing environmental loads [74].

\section{PECTINASES}

Pectinases are a complex heterogeneous group of enzymes which acts particularly on pectic substances. Pectinases act on and reduce the intracellular viscosity and tissue stiffness [113]. The activity of pectinases likewise affects the physical and chemical parameters that are essential for increment in the yield [34]. Pectinases comprise of three principal categories of enzymes; Polymethylesterase (PME), Polygalacturonase (PG), and Pectate lyase (PAL) [36, 44]. Polygalacturonases causes the breakdown of $\alpha$ (1-4) glycosidic linkage between the Galacturonic acid deposits. Pectate lyase [90] acts on pectin giving out oligosaccharides of $\alpha$ (1-4) connected galacturonic acid residues. Poly methyl esterase act on pectin methyl esters discharging methanol [47]. Organisms are known in their capacity to deliver pectinases active on particular substrate [108]. Psychrophilic yeast strains $C$. cylindricus and $M$. frigida isolated from soil of Abashiri [71], have been found to secrete numerous coldactive pectinolytic enzymes [71]. Eight cold adapted polygalacturonase producing yeasts have been isolated from frozen samples of Iceland, four of them having potential pectinases producing ability are $C$. larimarini, $C$. capitatum, C. macerans and $C$. aquaticus [12]. It has been showed that yeasts, for example, Kluyveromyces wickerhamii [68] and moulds such as, Aspergillus niger CH-Y-143 [3], are equipped with the ability to produce polygalacturonases constitutively.

\section{PECTIN}

Pectin is a structural polysaccharide found in cell wall and middle lamella of fruits and vegetables. The primary structure of pectin comprises of homopolymeric chain of partly methylated poly-a- $(1,4)$ - galacturonic acid [38, 46, 48]. Side chains of a-(1, 2) -L-rhamnosyl-a-(1, 4)- Dgalacturonosyl containing branch-points with L-arabinose and D-galactose can join the primary polymeric chain. Pectin may likewise contain residues of D-glucuronic acid, D-apiose, D-xylose and L-fucose connected to poly-a- $(1,4)$ D-galacturonic acid segments [77, 121]. Pectic substances are generally dispersed in fruits and vegetables and subsequently they form regular substrates for pectinases [35]. The carboxyl groups of galacturonic acid are esterified to some extent with methyl groups and neutralized by sodium, potassium or ammonium particles partly or totally. Different modifications of the backbone chain yields protopectin, pectic acid, pectinic acid and pectin [9]. 


\section{CLASSIFICATION OF PECTINASES}

Pectinases can be classified as given in the Table 1 .

Table 1 Classification of pectinases based on mode of action, substrate preferences and products Adopted from Sahay, [92].

\begin{tabular}{|c|c|c|c|c|}
\hline Enzyme & EC No & Substrate & Mode of action & Product (s) \\
\hline Protopectinase & & Protopectin & $\begin{array}{l}\text { Hydrolyse glycosidic bond at } \\
\text { sites with }>3 \text { nonmethylated GA }\end{array}$ & Water-soluble pectin \\
\hline \multicolumn{5}{|l|}{ De-esterifyer } \\
\hline PMGE & 3.1.1.11 & Pectin & Random cleavage of methyl ester & Pectic acid +Methanol \\
\hline PEE & 3.1.1.6 & Pectin & Random cleavage of ethyl ester & Pectic acid + Ethanol \\
\hline $\begin{array}{l}\text { De-polymeriser } \\
\text { a) Hydrolases } \\
\text { (i) PolyGAses }\end{array}$ & & Pectate & Cleave $\alpha-1,4$-glycosidic bond & \\
\hline EndoPG & 3.2 .1 .15 & Pectate & Random cleavage & Oligo-GA \\
\hline \multicolumn{4}{|c|}{ (ii) PolymethylGAses } & Mono-GA \\
\hline $\begin{array}{l}\text { EndoPMG } \\
\text { ExoPMG } \\
\text { (b) Lyases }\end{array}$ & & $\begin{array}{l}\text { Pectin } \\
\text { Pectin }\end{array}$ & $\begin{array}{l}\text { Random cleavage } \\
\text { Terminal cleavage } \\
\text { Cleave } \alpha-1,4 \text {-glycosidic bonds } \\
\text { by transelimination }\end{array}$ & $\begin{array}{r}\text { Oligomethyl-GA } \\
\text { Methylmono-GA } \\
\text { Unsaturated GA }\end{array}$ \\
\hline \multicolumn{5}{|c|}{ i) PolyGA lyases (PGL) } \\
\hline EndoPGL & 4.2.2.2 & Pectate & Random cleavage & Unsaturated GA \\
\hline ExoPGL & 4.2.2.9 & Pectate & Cleave penultimate bonds & Unsaturated di-GA \\
\hline $\begin{array}{l}\text { Oligo GA lyase } \\
\text { ii) Polymethyl } \\
\text { (PMGL) }\end{array}$ & $\begin{array}{l}\text { 4.2.2.6 } \\
\text { GA Lyase }\end{array}$ & Oligo-GA & $\begin{array}{l}\text { Cleave } \alpha-1,4 \text {-glycosidic bonds } \\
\text { in pectin by trans-elimination }\end{array}$ & mono-GA \\
\hline EndoPMGL & 4.2.2.1 & Pectin & Random cleavage & $\begin{array}{c}\text { Unsaturated Methyl } \\
\text { Oligo-GA }\end{array}$ \\
\hline ExoPMGL & & Pectin & Terminal cleavage & $\begin{array}{l}\text { Unsaturated methyl } \\
\text { Mono-GA }\end{array}$ \\
\hline
\end{tabular}

GA, Galacturonic acid; oligo-GA, oligogalacturonic acid; mono-GA, monogalacturonic acid

\section{BIOTECHNOLOGICAL APPLICATIONS OF COLD-ACTIVE PECTINASES}

Any industry trying to improve its performance needs to continue refining its methods to manage three essential variables: cost, time, and quality. The food industry isn't an exception. Currently food industries focus on the nutritional and sensory quality of the product $[2,71]$.

Food industry which is the biggest buyer of pectinases utilizes it to eliminate pectin in organic product (fruit) juice preparing. The crude juice acquired after tissue grinding and squeezing, contains suspended pectin originating from the fruit. This results into higher thickness and cloudiness, interfering in filtration causing a general drop in the productivity. Pectinases are added to expel this suspended pectin and enhance the process, but the enzyme being mesophilic in nature as majority of currently available pectnases are, requires higher temperatures $\left(50-60^{\circ} \mathrm{C}\right)$. At this temperature, there is risk of juice contamination and loss of unpredictable fragrant compounds. In the event if the enzymes are cold-active or psychrophilic pectinases, similar processes can be conducted at lower temperatures and thereby one can control contamination $[12,71]$, maintain the product's flavor [117] and increase potential of storage [82]. All the processes if carried out at low temperature, it results into massive saving of energy [12]. Commercial "pectinases" covers around $10 \%$ of the total general enzyme preparations which are broadly used in the food industry for juices, fruit drinks and wine generation [98]. The primary industrial use of pectinases was accounted for in 1930 [50] for the processing of apple juice.

Acidic pectic enzymes utilized in the fruit juice enterprises and wine making frequently originate from fungal sources, particularly from Aspergillus niger. These enterprises are concerned with the formation of commercial juice such as bright clear juices, (juice of apple, pear and grapes), juices with clouds (citrus juices, tomato juice and nectars), and unicellular products where the expectation is to protect the integrity of the plant cells by specifically hydrolyzing the polysaccharides of the middle lamella. The targets of enzymes differ in these three kinds of fruit and vegetable juices. These enzymes are added to upgrade the juice yield 
during pressing and stressing activities and to eliminate the suspensions to give shining clear juice without haze. In fruit and vegetable handling, the general method is the mash treatment with proper enzymatic preparations $[18,51$ and 83]. Juices with low viscosity, high clarity and high in nutrition are more attractive by consumers.

Cold-active pectinases plays a vital part to lessen the viscosity, increment in the yield and clarification of juice by liquefaction of pulps, evacuate off the peels $[18,47,48$, and 58] and in maceration of vegetables to deliver the products like pastes and purees [28, 108, and 115]. Depectinization relies on the organization of juice, the kind of catalyst utilized and the time consumed [118]. For depectinization of juices (orange, apple, pear, grapes, guava, and so forth) with pectinases the $\mathrm{pH}$ conditions needs from 3-6 [23, 107], action time from $5 \mathrm{~min}$ to 6 hours [4, 105, 107, and 115], temperature underneath $50^{\circ} \mathrm{C}[4,48$, and 105] and enzyme amount about 0.06 to $0.135 \% \mathrm{v} / \mathrm{w}[4,24]$.

Pectinolytic enzymes have additionally been coupled in relationship with other cell wall degrading enzymes, for example, cellulases and hemicellulases [11]. Around $25 \%$ increase in pineapple juice recovery was acquired, when a blend of two commercial catalysts pectinase and hemicellulase was utilized at the extraction temperature of $40^{\circ} \mathrm{C}$ against control [114]. The utilization of pectinases and hemicellulase in the processing of pineapple mash expanded the juice extraction as well as guaranteed the most elevated quality of the finished products $[48,52]$. Expanded juice yield is predominantly because of the capacity of enzymes to degrade the cell walls, in this manner essentially brings down the viscosity of the cloud juices and subsequently limits membrane clogging in the course of filtration activities [18, 26]. Soares and colleagues [107] explained that the yield of fruit (pear, guava, banana, papaya) and vegetable (carrot, beet) juice was enhanced essentially by pectinases treatment and the material was pressed more effortlessly than the control and the residual dry weight of solid deposits diminished in the range from 5 to $64 \%$.

Natural product treatment with pectinases assists in the release of phenolic contents from the fruit-skin [100]. These phenolic components have many health benefits as antioxidant such as protection from coronary illness and certain cancers [65]. Phenolic content was higher up to $15 \%$ in the enzyme treated dragon fruit beverage then unprocessed beverage [4]. A few reports also report the utility of simultaneous utilization of ultrasound and pectinases for this purpose $[24,55]$. When acerola and grape mashes were treated with ultrasound and pectinases together the amount of juice extracted was more as compared to ultrasonic or enzymatic treatments used singly [24]. As of late, scientific and industrial endeavors to find and develop novel cold adapted enzymes have expanded significantly. The natural qualities of cold adapted enzymes, high action at low temperatures and destruction in response to heat, are to a great degree profitable for various biotechnological applications in a wide range of industries for food and beverage preparation [17, 30]. As a result, psychrophilic enzymes are eliminating mesophilic enzymes in a wide range of industrial procedures.

Extremophiles are powerful sources of extremozymes, which demonstrate utmost strength under extreme conditions. Subsequently, much consideration has been given to the microorganisms that can flourish in extraordinary conditions as source of extremozymes. Biocatalysis applying extremophiles and also extremozymes is quickly being changed from academic science to industrially applicable innovation. Each set of the extremophiles has one kind of uniqueness, which can be cultivated to yield enzymes with an extensive variety of application possibilities [1, 40]. Psychrophilic enzymes obtained from psychrophilic yeasts display high action at low and moderate temperatures and hence offer potential economic advantages $[6,53]$ promulgate that as a part of low temperature fermentation psychrophilic yeast could be utilized. Cold-active enzymes have pulled in awesome consideration as biocatalysts since they can oppose very unfavorable response conditions in industry [27, 91, and 104]. There are almost 4000 compounds known today and of these around 200 are utilized commercially [101]. Psychrophilic yeast has been accounted for being utilized as a part of low temperature fermentation $[56,79]$. The higher catalytic action of psychrophiles at low and modest temperatures put forth potential economic advantages [17]. There is industrial trend to treat foodstuffs under mild conditions with a specific aim to avoid decay, and changes in taste and nutritional value at ambient surrounding temperature. Thus, for food processing cold-active enzymes are utilized $[33,90]$. With appealing molecular adaptabilities cold-active enzymes have opened up new potential regions of applications [91, 104]. Processes catalyzed by cold-active enzymes have two favorable benefits, they can possibly manage the procedures by saving energy [17, 27], and they shield the process from contamination [33]. Industrial enzymes are mostly of microbial origin.

The capacity of thermo labile enzymes has specific significance to the food industry where it is critical to evade any change to heat-sensitive substrates and product. This is additionally of advantage in successive procedures (example, molecular biology) where the activities of enzyme should be ended before the next procedure is undertaken; with coldadapted catalysts this may be possible by heat inactivation as opposed to chemical extraction [33, 90]. In food industry, juice clarification at low temperature could be done utilizing cold-active enzymes from psychrophilic yeasts.

The enzymes generated by microorganisms are exploited in different industries, for example, dairy, food, detergents, textile, pharmaceutical, cosmetic, biodiesel industries, and to 
assemble agrochemicals and new polymeric materials [42, 97]. A few yeast strains have been investigated with respect to the biological treatment of industrial and domestic waste water [72, 114]. It was reported that psychrophilic yeast Candida sp. obtained from water test samples from Lake Vanda in Antarctica can be utilized for dissolved organic matter treatment at low temperatures [49].

Grape juice isn't consumed in vast amount because of its sweetness (around $200 \mathrm{~g} / \mathrm{l}$ sugars) or excessively acidic nature (around $10 \mathrm{~g} / \mathrm{l}$ tartaric acid) despite the fact that, it is employed in combination with other juices such as apple. This grape juice innovative assimilation has looked into by Pederson as well as by Luh and Kean [57, 75]. Because of high pectic substances (5-10 g/l) grapes are hard to crush and press. They are destemmed, pressed and heated to $60^{\circ} \mathrm{C}$ or $80^{\circ} \mathrm{C}$ to discharge color from skins such as for red grapes and thus the endogenous polyphenoloxidase is destroyed. Pectic enzymes from organisms especially Aspergillus niger, Penicillium notatum or Botrytis cinerea are valuable in making wine. The juices of berries, peaches, apples, pears and diverse fruits are exploited and wines from grapes are produced in vast volumes $[31,80]$. Wine processing industry likewise perceives the significance of acidic pectinases [89] where the enzymes can be utilized at various stages. The pectinases added for the fruit crushing increases the juice yield and furthermore quickens the arrival of anthocyanins into the juice. Suspended particles are settled out when pectinases are added during the pre-fermentation or fermentation stage. To increase wine clarity and filtration rate, enzyme is added after fermentation $[48,73]$.

The fundamental functions of pectinolytic enzymes in the process of wine making are to help the extraction procedure, increased juice yield, make easy filtration and improve the flavor and color [18]. Enzymatically treated wines demonstrated greater stability with less filtration time in contrast with control wines [14, 44]. Before the inoculums addition, pectinolytic treatment of macerated fruits brought the enhanced attributes of wine [85, 81]. Clarification of must before the beginning of alcoholic fermentation likewise enhances the sensory attributes of white wine [84]. It was also revealed that the larger amounts of liquor generation in matured grape must, pretreated with pectinolytic enzymes and observed increment in iso-amyl liquor and 2-phenyl ethanol and a decline in n-propanol concentration [15]. Combined impact of fermentation by yeast cultures and pectinases treatment on ethanol production was displayed by Reddy and Reddy [84]. Different reports have demonstrated that, by adding pectinolytic enzymes in the winemaking process, the higher levels of methanol in wine are obtained because of the pectin esterase activity $[86,99]$. Methanol is harmful and its most extreme focus in wine is its regulation to be directed. In this way, pectin esterase ought to be in low amount in commercial products.
The present food and wine industry aim to replace hightemperature processes with low-temperature processes. Processing at low-temperature provides economic and ecologically favorable advantage. A few advantages of lowtemperatures processing are energy saving, avoid contamination and decay, maintenance of labile and unstable flavor compounds, minimization of unfortunate chemical responses that may happen at higher temperatures, and a higher level of control over cold-active compounds as they can be inactivated at increased temperatures [82, 94]. Pectinases demonstrating high polygalacturonase activity are added to fruit juices to balance out the cloud juices of citrus, purees and nectar, for example apricot nectar depicts cloud loss that can be evaded by homogenization [103]. Fruit pulp cells contain primary cell wall just comprises of around $90 \%$ polysaccharide and $10 \%$ protein [120]. Addition of pectic enzymes gives cloud-stable apricot nectar, where as homogenization alone fails to accomplish cloud stability. To enhance juice extraction exogenous compounds are used to treat fruit pulps [20].

Additionally pectinases are being exploited as a part of biorefineries for pectin hydrolyzation that occurs in pectin-rich agro-industrial wastes [13]. These wastes are changed into basic sugars with the goal that they could be changed over into bio-ethanol or utilized as fermentable sugars [22, 39]. To modify polysaccharides present in the plant cell wall into basic sugars distinctive enzymes for example pectinases, hemicellulases and cellulases are being employed [10]. Duckweed (Landoltia punctata) treated with a pectinases amount of 26.54 pectin transeliminase unit/g mash at $45^{\circ} \mathrm{C}$ for 5 hours results about $14.2 \%$ increase in glucose when compared with the raw mash. This glucose is additionally exploited in preparation of $30.8 \pm 0.8 \mathrm{~g} / \mathrm{L}$ ethanol utilizing duckweed as the feedstock [21].

The wastewater from the citrus-preparing industry contains pectinaceous materials that are deteriorated by microorganisms during the activated sludge-treatment [112]. Vegetable food preparing enterprises discharge pectin containing wastewaters as by-product. Pretreatment of these wastewaters with pectinolytic catalysts encourages removal of pectinaceous material and renders it appropriate for deterioration by activated sludge-treatment [38, 44]. A delicate rot pathogen, Erwinia carotovora (FERM P-7576) which privileged interior endo-pectate lyase, has been accounted for to be helpful in the pretreatment of pectinaceous wastewater [111].

\section{CONCLUSION AND FUTURE SCOPE}

More microbes from cold areas on the earth need to be explored as source cold active enzymes. Cold-active pectinolytic enzymes with specific set of catalytic features need to be studied and further studies to employ these 
pectinases to various industrial processes are also urgently required in view of the above said benefits.

\section{REFERANCES}

[1]. M.W.W. Adams, F.B. Perler, R.M. Kelly, "Extremozymes: Expanding the limits of biocatalysis", Biotechnology, Vol. 13, pp. 662-668, 1995.

[2]. V. Adapa, L.N. Ramya, K.R.S.S. Rao, "Cold Active Pectinases: Advancing the Food Industry to the Next Generation", Applied Biochemistry and Biotechnology, Vol. 172, pp. 2324-2337, 2014.

[3]. G. Aguilar and C. Huitro, "Constitutive exo-pectinase produced by Aspergillus sp. CH-Y-1043 on different carbon source", Letters in Biotechnology, Vol. 12, pp. 655-660, 1990.

[4]. A.R.N. Aliaa, M.K.S. Mazlina, F.S. Taip, "Impact of commercial pectolytic enzymes on selected properties of white dragon fruit juice”, Journal Instant Engineering Malaysia, Vol. 71, pp. 25-31, 2010.

[5]. I. Alkorta, C. Garbisu, J.L. Serra, "Industrial applications of pectic enzymes: a review" Process Biochemistry, Vol. 33, pp. 2128, 1998.

[6]. D. Allen, A.L. Huston, L.E. Wells, J.W. Deming, "Biotechnological use of psychrophiles", In Encyclopedia of Environmental Microbiology, Vol. 1, pp. 1-17, 2001.

[7]. G.J. Alphons, E. Voragen, C.E. Gerd-Jan, P. Rene, E. Verhoef, A. Henk, "Review Article: Pectin, a versatile polysaccharide present in plant cell walls". Structural Chemistry, Vol. 20, pp. 263-275, 2009

[8]. G. Antranikian, "Microbial degradation of natural products", In: Winkelmann General Edition, pp. 27-51, 1992.

[9]. J.N. Be Miller, "An introduction to pectin: structure and properties, chemistry and functions of pectin", American chemical society, Vol. 310, pp. 2-12, 1986.

[10]. G. Beldman, F.M. Rombouts, A.G.J. Voragen, W. Pilnik, "Application of cellulase and pectinase from fungal origin for the liquifaction and saccharification of biomass", Enzymatic Microbial Technology, Vol. 6, pp. 503-507, 1984.

[11]. M.K. Bhat, "Cellulases and related enzymes in biotechnology", Advanced Biotechnology, Vol. 18, pp. 355-383, 2000.

[12]. H. Birgisson, O. Delgado, L.G. Arroyo, R. Hatti-Kaul, B. Mattiasson, "Cold-adapted yeasts as producers of cold-active polygalacturonase", Extremophiles, Vol. 7, pp. 185-193, 2003.

[13]. A. Biz, F.C. Farias, F.A. Motter, D.H. de Paula, P. Richard, N. Krieger, D.A. Mitchell, "Pectinase activity determination: an early deceleration in the release of reducing sugars throws a spanner in the works", Vol. 9, doi: 10.1371/ journal.pone.0109529, 2014.

[14]. M.K. Blunt, "Cellulases and related enzymes in biotechnology", Advanced Biotechnology, Vol. 18, pp. 355-383, 2000.

[15]. A. Bosso, "On-skin maceration during white wine making in the presence of pectolytic enzyme preparations", Vini d' Italia, Vol. 34, pp. 25-40, 1993.

[16]. R. Cavicchioli, and T. Tortsen, "Extremophilic Encyclopaedia of Microbiology", 2nd edition (Lederberg Journal edition), Academic Press, London, Vol. 2, pp. 317-337, 2000.

[17]. R. Cavicchioli, K.S. Siddiqui, D. Andrews, K.R. Sowers, "Low temperature extremophiles and their applications", Current Opinion in Biotechnology, Vol. 13, pp. 253-261, 2002.

[18]. A. Chaudhri and V. Suneetha, "Microbially derived pectinases: a review". Journal in Pharmaceutical Biological Sciences, Vol. 2, pp. 01-05, 2012.

[19]. S. Chawanit, S. Surang, C. Lerluck, P. Vittaya, V. Pilanee, S. Prisnar, "Screening of pectinase producing bacteria and their efficiency in Biopulping of paper mulberry bark". Science Asia, vol. 33, pp.131-135, 2007.
[20]. K. Chen Chin, A. Yuguwa, H. Yamaoto, "Enzymic degumming of pineapple and pineapple mill juices", Journal in Food Sciences. Vol. 49, pp. 1327-1329, 1984.

[21]. Q. Chen, Y. Jin, G. Zhang, Y. Fang, Y. Xiao, H. Zhao, "Improving production of bioethanol from duckweed (Landoltia punctata) by pectinase pretreatment", Energies, Vol. 5, pp. 30193032, 2012.

[22]. R.M. Collares, L.V.S. Miklasevicius, M.M. Bassaco, N.G.P. Salau, M.A. Mazutti, D.A. Bisognin, L.M. Terra, "Optimization of enzymatic hydrolysis of cassava to obtain fermentable sugars", Journal of Zhejiang University Sciences (Biomedical. and Biotechnological), Vol. 13, pp. 579-586, 2012.

[23]. S. Croaka and M. Corredig, "The role of pectin in orange juice stabilization: effect of pectin methylesterase and pectinase activity on the size of cloud particles", Food Hydrocoll, Vol. 20, pp. 961-965, 2006.

[24]. B.K. Dang, T.V. Huynh, V.V.M. Le, "Simultaneous treatment of acerola mash by ultrasound and pectinase preparation in acerola juice processing: optimization of the pectinase concentration and pectolytic time by response surface methodology", International Journal of Food Resources, vol. 19, pp. 509-513, 2012.

[25]. B.P. Danielle, C.M, Alexandre, G. Eleni, C.C. Eleonora, "Pectin and Pectinases: Production, Characterization and Industrial Application of Microbial Pectinolytic Enzymes", The Open Biotechnology Journal, Vol. 3, pp. 9-18, 2009.

[26]. L.M.J. De Carvalho, I.M. de Castro, C.A.B. de Silva, "A study of retention of sugars in the process of clarification of pineapple juice (Ananas comosus, L. Merril) by micro and ultra-filtration", Journal Food Engineering, Vol. 87, pp. 447-454, 2008.

[27]. J.W. Deming, "Deep ocean environmental biotechnology", Current Opinion Biotechnology, Vol. 9, pp. 283-287, 1998.

[28]. N. Demir, J. Acar, M. Sariolu, M. Mutlu, "The use of commercial pectinases in fruit juice industry. Part 3: immobilized pectinase for mash treatment", Journal Food Engineering, Vol. 47, pp. 275280, 2000.

[29]. G. Feller and C. Gerday, "Psychrophilic enzymes: molecular basis of cold adaptation", Cellular and Molecular Life Sciences, Vol. 53, pp. 830-841, 1997.

[30]. G. Feller and C. Struvay, "Optimization to low temperature activity in psychrophilic enzymes". International Journal of Molecular Sciences, Vol. 13, pp. 11643-11665, 2012.

[31]. M.V. Fogarty and C.T. Kelly, "Pectic enzymes, In: Fogarty, M.W. (Edition), Microbial Enzymes and Biotechnology", Applied Science Publishers, London, pp. 131-182, 1983.

[32]. G. Garg, A. Singh, A. Kaur, R. Singh, J. Kaur, R. Mahajan, "Microbial pectinases: an ecofriendly tool of nature for industries, Review article", Journal 3 Biotechnology, Vol. 3, pp. 6-47, 2016.

[33]. C. Gerday, M. Aittaleb, M. Bentahir, J.P. Chessa, P. Claverie, T. Collins, S. D“Amico, J. Dumont, "Cold-adapted enzymes: from fundamentals to biotechnology", Trends in Biotechnology, Vol. 18, pp. 103-107, 2000.

[34]. S.N. Gummadi and D.S. Kumar, "The Effect of microbiological parameters on production of pectin lyase and pectate lyase by Debaryomyces nepalensis: A statistical approach", Research Journal of Microbiology, Vol. 1, pp. 220-227, 2006.

[35]. S.N. Gummadi and T. Panda, "Purification and biochemical properties of microbial pectinases: a review", Process Biochemistry, Vol. 38, pp. 987-996, 2003.

[36]. A. Haidar and M.F. Hassan, "Pectinase production in a defined medium using surface culture fermentation", International Journal of Indigenous Chemistry, Vol. 1, pp. 5-10, 2010.

[37]. B. Hamid, R.S. Rana, D. Chauhan, P. Singh, F.A. Mohiddin, S. Sahay, I. Abidi, "Psychrophilic yeasts and their biotechnological applications- A review", African Journal of Biotechnology, Vol.13, pp. 2188-2197, 2014. 
[38]. G.S. Hoondal, R.P. Tiwari, R. Tiwari, N. Dahiya, Q.K. Beg, "Microbial alkaline pectinases and their industrial applications: a review", Applied Microbial Biotechnology, Vol. 59, pp. 409418, 2002.

[39]. A.B.M.S. Hossain, S.A. Ahmed, M.A. Ahmed, M.A.A. Faris, M.S.M. Annuar, M. Hadeel, H. Norah, "Bioethanol fuel production from rotten banana as an environmental waste management and sustainable energy", African Journal of Microbiology Research, Vol. 5, pp. 586-598, 2011.

[40]. D.W. Hough, and M.J. Danson, "Extremozymes", Current Opinion Chemical Biology, Vol. 3, pp. 39-46, 1999.

[41]. C. Ivana, A. Agustín, F. Dante, G. Gabriela, V. Silvana, C. Sebastián, "Pectinolytic yeasts from cold environments: novel findings of Guehomyces pullulans, Cystofilobasidium infirmominiatum and Cryptococcus adeliensis producing pectinases", Extremophiles, DOI 10.1007/s00792-016-0904-0, 2016.

[42]. K.E. Jaeger, and T. Eggert, "Lipases for biotechnology", Current Opinion in Biotechnology, Vol. 13, pp. 390-397, 2002.

[43]. L. Janssens, H.L. de Pooter, E.J. Vandamme, "Production of flavours by microorganisms". Process Biochemistry, Vol. 27, pp. 195-215, 1992.

[44]. R.S. Jayani, S. Saxena, R. Gupta, "Microbial pectinolytic enzymes: a reviw", Process Biochemistry, Vol. 40, pp. 29312944, 2005

[45]. M. Jose, R. Nogales, N, Ortega, M.P. Mateos, M. Busto, "Pectin hydrolysis in a free enzyme membrane reactor: An approach to the wine and juice clarification", Food Chemistry, Vol. 107, pp. 112-119, 2008.

[46]. M.Q. Kapoor, B. Khalil Beg, K. Bhushan, S. Dadhich, G.S. Hoondal, "Production and partial purification and characterization of a thermo-alkali stable polygalacturonase from Bacillus sp. MG-cp-2", Process Biochemistry, Vol. 36, pp. 467-473, 2000.

[47]. S.O. Kareem, and A.A. Adebowale, "Clarification of orange juice by crude fungal pectinases from citrus peel", Nigerian Food Journal, Vol. 25, pp. 130-137, 2007.

[48]. D.R. Kashyap, P.K. Vohra, S. Chopra, R. Tewari, "Applications of pectinases in the commercial sector: a review", Bioresource Technology, Vol. 77, pp. 215-227, 2001.

[49]. H. Katayam, J. Nishikawa, Y. Hira, "Biological treatment of dissolved organic matter by Antarctic psychropylic yeast cells, Mizushori gijutsu (Water purification and liquid wastes treatment)", Vol. 38, pp. 1-4, 1997.

[50]. Z. Kertesz, "A new method for enzymatic clarification of unfermented apple juice", New York State Agricultural Experimentation Station (Geneva), U.S. Patent 1,932,833, Bull No. 689, 1930.

[51]. M. Khan, E. Nakkeeran, S.U. Kumar, "Potential application of pectinases in developing functional foods", Annual Review of Food Science and Technology, Vol. 4, pp. 21-34, 2013.

[52]. A. Kilara, "Enzymes and their uses in the processed apple industry: a review", Process Biochemistry, Vol. 35, pp. 35-41, 1982.

[53]. Y. Kourkoutas, A. Koutinas, M. Kanellaki, I. Banat, R. Marchant, "Continuous wine fermentation using psychrophilic yeast immobilizedon apple cuts at different temperatures", Food Microbiology, Vol. 19, pp. 127-134, 2002.

[54]. G. Kaur, S. Kumar, T. Satyanarayana, "Production, characterization and application of a thermostable polygalacturonase of a thermophilic mould Sporotrichum thermophile" Bioresource Technology, Vol. 94, pp. 239-243, 2004.

[55]. L.N. Lieu and V.V.M. Le, "Application of ultrasound in grape mash treatment in juice processing", Ultrason Sonochemistry, Vol. 17, pp. 273-279, 2010.
[56]. D. Liu, R. Schmid, M. Rusnak, "Functional expression of Candida antarctica lipase B in the Escherichia coli cytoplasm-a screening system for a frequently used biocatalyst", Applied Microbial Biotechnology, Vol. 72, pp. 1024-1032, 2006.

[57]. B. Luh, and C. Kean, "Canning of fruit". In: Woodroof, Journal Luh, B. (Edition), Commercial Fruit Processing, AVI Publishing, Westport, CT, 1975.

[58]. E.A. Makky, and M.M. Yusoff, "Bioeconomy: pectinases purification and application of fermented waste from Thermomyces lanuginosus", Journal Medical Bioengineering, Vol. 4, pp. 76-80, 2015.

[59]. R. Margesin, and F. Schinner, "Properties of cold-adapted microorganisms and their potential role in biotechnology", Journal Biotechnology, Vol. 33, pp. 1-14, 1994.

[60]. R. Margesin, V. Fauster, P.A. Fonteyne, "Characterization of cold-active pectate lyases from psychrophilic Mrakia frigid", Letters in Applied Microbiology, Vol. 40, pp. 453-459, 2005.

[61]. R. Margesin, P.A. Fonteyne, F. Schinner, J.P. Sampaio, "Rhodotorula psychrophila sp. Rhodotorula psychrophenolica $s p$. and Rhodotorula glacialis sp. novel psychrophilic basidiomycetous yeast species isolated from alpine environments", International Journal of Systematic and Evolutionary Microbiology, Vol. 57, pp. 2179-2184, 2007 a.

[62]. R. Margesin, G. Neuner, K.B. Storey, "Cold-loving microbes, plants, and animals-fundamental and applied aspects", Naturwissenschaften, Vol. 94, pp. 77-99, 2007b.

[63]. T.P. Maria, L. Pedro, R. Fernando, L. Romojaro, "Pectic enzymes in fresh fruit processing: optimization of enzymic peeling of oranges", Process Biochemistry, Vol. 32 pp. 43-49, 1997.

[64]. M.G. Merın, L.M. Mendoza, M.E. Farıas, V.I.M. Ambrosini, "Isolation and selection of yeasts from wine grape ecosystem secreting cold-active pectinolytic activity", International Journal of Food Microbiology, Vol. 147, pp. 144-148, 2011.

[65]. N.J. Miller and C.A. Rice-Evans, "The relative contributions of ascorbic acid and phenolic antioxidants to the total antioxidant activity of orange and apple fruit juices and blackcurrant drink", Food Chemistry, Vol. 60, pp. 331-337, 1997.

[66]. R.Y. Morita, "Marine psychrophilic bacteria oceanoger", Marine biolog Annual Review, Vol. 4, pp. 105-121, 1966.

[67]. R. Y. Morita, "Psychrophilic bacteria", Bacteriology Review, Vol. 39, pp. 144-167, 1975.

[68]. S. Moyo, B.A. Gashe, E.K. Collison, S. Mpuchane, "Optimizing growth conditions for the pectinolytic activity of $K$. wickerhamii by using response surface methodology", International Journal of Food Microbiology, vol. 85, pp. 87-100, 2003.

[69]. G.S.N. Naidu and T. Panda, "Production of Pectolytic Enzymes A Review", Bioprocess Engineering, Vol. 19, pp. 355-361, 1998.

[70]. T. Nakagawa, T. Nagaoka, T. Miyaji, N. Tomizuka, "Cold-active polygalacturonase from psychrophilic Basidiomycetous yeast Cystofilobasidium capitatum strain PPY-1", Bioscience, Biotechnology and Biochemistry, Vol. 69, pp. 419-421, 2005.

[71]. T. Nakagawa, T. Nagaoka, S. Taniguchi, T. Miyaji, N. Tomizuka, "Isolation and characterization of psychrophilic yeasts producing cold-adapted pectinolytic enzymes", Letters in Applied Microbiology, Vol. 38, pp. 383-387, 2004.

[72]. S. Ohno and S. Suzukia, "Treatment of highly concentrated organic wastewater by yeasts", Yosui to Haisui Journal of Water Wastes, Vol. 33, pp. 664-668, 1991.

[73]. J.O. Oliyad, "Pectinase: Substrate, Production and their Biotechnological Applications", International Journal of Environment Agriculture and Biotechnology, Vol. 2, pp. $1007-$ 1014, 2017.

[74]. S.R. Patil and A. Dayanand, "Production of pectinases from deseeded sunflower head by Aspergillus niger in submerged and solid-state conditions", Bioresource Technology, Vol. 97, pp. 2054-2058, 2006. 
[75]. C. Pederson, "Grape juice", In: Nelson, Tresselier, D. (Edition), Fruit and Vegetable Juice Process Technology, AVI Publishing, Westport, CT, pp. 268-309, 1980.

[76]. D.B. Pedrolli, E. Gomes, R. Monti, E.C. Carmona, "Studies on productivity and characterization of polygalacturonase from Aspergillus giganteus submerged culture using citrus pectin and orange waste". Applied Biochemistry and Biotechnology, Vol. 144, pp. 191-200, 2008.

[77]. S. Perez, M.A. Rodríguez-Carvajal, T. Doco, "A complex plant cell wall polysaccharide: rhamnogalacturonan II, A structure in quest of a function", Biochimistry, Vol. 85, pp. 109-121, 2003.

[78]. S. Perez, M.A. Rodríguez-Carvajal, T. Doco, "A complex plant cell wall polysaccharide: rhamnogalacturonan II, A structure in quest of a function", Biochimistry, Vol. 85, pp. 109-121, 2003.

[79]. J. Pfeffer, S. Richter, J. Nieveler, C.E. Hansen, R. Rhlid, R. Schmid, M. Rusnak, "High yield expression of lipase A from Candida antarctica in the methylotrophic yeast Pichia pastoris and its purification and characterization", Applied Microbiology and Biotechnology, Vol. 72, pp. 931-938, 2006.

[80]. W. Pilnik, "Enzyme in the beverage industry", In: Dupuy, P. (Edition), Use of Enzymes in Food Technolopgy Techniwue et Documentation Lavosier, Paris, pp. 425-450, 1982.

[81]. K.G. Praveen, and V. Suneetha, "A cocktail enzyme - pectinases from fruit industrial dump sites: a review", Resource Journal Pharmaceutical Biological and Chemical Sciiences, Vol. 5, pp. 1252-1258, 2014.

[82]. K.K. Pulicherla, G. Mrinmoy, S. Kumar, K.R. SambasivaRao, "Psychrozymes- the next generation industrial enzymes", Journal Marine Sciences Resource Development, Vol. 1, doi: 10.4172/2155-9910.1000102, 2011.

[83]. M.F. Ramadan, and J.T. Moersel, "Impact of enzymatic treatment on chemical composition, physicochemical properties and radical scavenging activity of goldenberry (Physalis peruviana) juice", Journal Science in Food Agriculture, Vol. 87, pp. 452460, 2007.

[84]. L.V. Reddy, and O.V. Reddy, "Production, optimization and characterization of wine from mango (Mangifera indica Linn.)", Natural Product Radiance, Vol. 8, pp. 426-435, 2009.

[85]. I. Revilla, and M.L. Ganzalez-san jose, "Addition of pectolytic enzymes: an enological practice which improves the chromaticity and stability of red wines", International Journal of Food Scienc and Technology, Vol. 38, pp. 29-36, 2003.

[86]. I. Revilla, and M.L. Gonza lez-San Jose, "Methanol release during fermentation of red grapes treated with pectolytic enzymes", Food Chemistry, Vol. 63, pp.307-312, 1998.

[87]. G.L. Robertson, "Pectic enzymes and wine making", Food Technology New Zealand, Vol. 12, pp. 34-35, 1977.

[88]. C.H. Robinson, "Cold adaptation in Arctic and Antarctic fungi", Journal New Phytologist, Vol. 151, pp. 341-353, 2001.

[89]. A. Roldán, P. Victor, C. Ildefonso, P. Luis, "Evolution of Resveratrol and Piceid contents during the industrial Winemaking process of sherry wine", Journal of Agricultural and Food Chemistry, Vol. 58, pp. 4268-73, 2010.

[90]. N.J. Russell, and T. Hamamoto, "Psychrophiles in Extremophiles: Microbial Life in Extreme Environments", Edited by Horikoshi K, Grant WD.New York: Wiley-Liss. pp. 25-45, 1998.

[91]. S. Sahay, B. Hamid, P. Singh, K. Ranjan, D. Chauhan, R.S. Rana, V.K. Chaurse, "Evaluation of pectinolytic activities for oenological uses from psychrotrophic yeasts", Letters in Applied Microbiology, Vol. 57, pp. 115-121, 2013.

[92]. S. Sahay, "Wine enzymes: Potential and practices", In: Kuddus, M. (Edition) Enzymes in Food Biotechnology: Production, Applications, and Future Prospects, Elsevier, (in press), 2018.

[93]. Y. Sangeeta, K.Y. Pramod, Y. Dinesh, S.Y. Kapil Deo, "Pectin lyase: A review", Process Biochemistry, Vol. 44, pp. 1-10, 2009.
[94]. F. Sarmiento, R. Peralta, J.M. Blamey, "Cold and hot extremozymes: industrial relevance and current trends", Frontier Bioengineering Biotechnology, Vol. 3, pp. 148, 2015.

[95]. R. Sarvamangala and D. Patil, "Exploration of Regional Agrowastes for the Production of Pectinase by Aspergillus niger", Food Technology Biotechnology, Vol. 44, pp. 289-292, 2006.

[96]. N. Sathyanarayana, D. Gummadi, K. Sunil, "Optimization of chemical and physical parameters affecting the activity of pectin lyase and pectate lyase from Debaryomyces nepalensis: A statistical approach", Biochemical Engineering Journal, Vol. 30, pp. 130-137, 2006.

[97]. R.K. Saxena, P.K. Ghosh, R. Gupta, W.S. Davidson, S. Bradoo, R. Gulati, "Microbial lipases: potential biocatalysts for the future industry", Current Science, Vol. 77, pp. 101-115, 1999.

[98]. M. Semenova, O. Sinitsyna, V. Morozova, "Use of a preparation from fungal pectin lyase in the food industry", Applied Biochemistry Microbiology, Vol. 42, pp. 598-602, 2006.

[99]. M. Servili, A.L. Begliomini, G. Montedoro, M. Petruccioli, F. Federici, "Utilisation of a yeast pectinase in olive oil extraction and red wine making processes", Journal Sciences Food Agriculture, Vol. 58, pp. 253-260, 1992.

[100]. A. Sharma, A. Shrivastava, S. Sharma, R. Gupta, R.C. Kuhad, "Microbial pectinase and their application", In: Singh A (edition) Kuhad RC. Biotechnology for environmental management and resource recovery, Springer Science and Business Media, pp. 107-124, 2013.

[101]. R. Sharma, Y. Chisti, U.C. Banerjee, "Production, purification, Characterization and applications of lipases", Advanced Biotechnology, Vol. 19, pp. 627-662, 2001.

[102]. G. Shefali, K. Mukesh, K.S. Krishna, M.N. Lavanya, C.K. Ramesh, "Production and recovery of an alkaline exopolygalacturonase from Bacillus subtilis RCK under solid-state fermentation using statistical approach", Bioresource Technology, Vol. 99, pp. 937-945, 2008.

[103]. H.A.I. Siliha and W. Pilnik, "Cloud stability of apricot nectar", Ber Wiss Technology Komm IFU XVIII, pp. 325-334, 1985.

[104]. P. Singh, B. Hamid, M.A. Lone, K. Ranjan, A. Khan, V.K. Chaurse, S. Sahay, "Evaluation of pectinase activity from the psychrophilic fungal strain Truncatella angustata-BPF5 for use in wine industry", Journal Endocytobios Cell Resource, Vol. 22, pp. 57-61, 2012

[105]. S. Singh, and R. Gupta, "Apple juice clarification using fungal pectinolytic enzyme and pecttin", Indian Journal of Biotechnology, Vol. 3, pp. 573-576, 2004.

[106]. C. Sittidilokratnab, S. Suthirawuta, L. Chitradona, V. Punsuvonc, P. Vaithanomsatb, P. Siriachab, "Screening of pectinases producing Bacteria and their efficiency in Biopulping of paper mulberry bark", Science Asia, Vol. 33, pp. 131-135, 2007.

[107]. M.M.C.N. Soares, R. da Silva, E.C. Carmona, E. Gomes, "Pectinolytic enzyme production by Bacillus species and their potential application on juice extraction", Journal Microbial Biotechnology, Vol. 17, pp.79-82, 2001.

[108]. H.K. Sreenath, K.R. Sudarshanakrishna, K. Santhanam, "Improvement of juice recovery from pineapple pulp/residue using cellulases and pectinases", Journal. Fermentation Bioengineering, Vol. 78, pp. 486-488, 1994.

[109]. V. Suneetha and A.K. Zaved, "Actinomycetes: Sources for Soil Enzymes", Soil Enzymology, Soil Biology- 22, G. Shukla and A. Varma (edition) Springer-Verlag Berlin Heidelberg pp. 259-269, 2010.

[110]. O. Sunnotel and P. Nigam, "Pectinolytic activity of bacteria isolated from soil and two fungal strains during submerged fermentation", World Journal Microbial Biotechnology, Vol. 18, pp. 835-839, 2002. 
[111]. H. Tanabe and Y. Kobayashi, "Plant tissue maceration caused by pectinolytic enzymes from Erwinia spp. under alkaline conditions", Agriculture Biology and Chemistry, Vol. 51, pp. 2845-2846, 1987.

[112]. H. Tanabe, Y. Kobayashi, I. Akamatsu, "Pretreatment of pectic wastewater from orange canning by soft-rot Erwinia carotovora", Journal Fermentation Technology, Vol. 64, pp. 265268, 1986.

[113]. R.P. Tatiana and F. Flavio, "Extraction and assay of pectic enzymes from Peruvian carrot (Arracacia xanthorriza Bancroft)", Food Chemistry, Vol. 89, pp. 85-92, 2005.

[114]. Thanh and Simard, "Biological treatment of wastewater by yeasts", Journal Water Pollution Control Federation, Vol. 45, pp. 674-680, 1973.

[115]. B.N. Tochi, Z. Wang, S.Y. Xu, W. Zhang, "The Influence of a pectinase and pectinases/hemicellulases enzyme preparations on percentage pineapple juice recovery, particulates and sensory attributes", Pakistan Journal of Nutrition, Vol. 8, pp. 1184-1189, 2009.
[116]. E.F. Torres, T.V. Sepulveda, G.V. Gonzalez, "Production of hydrolytic depolymerising pectinases", Food Technology Biotechnology, Vol. 44, pp. 221-227, 2006.

[117]. L.V. Truong, H. Tuyen, E. Helmke, L.T. Binh, T. Schweder, "Cloning of two pectatelyase genes from the marine Antarctic bacterium Pseudoalteromonas haloplanktis strain ANT/505 and characterization of the enzymes", Extremophiles, Vol. 5, pp. 3544, 2001.

[118]. A. Versari, S. Biesenbruch, D. Barbanti, P.J. Farnell, S. Galassi, "Effects of pectolytic enzymes on selected phenolic compounds in strawberry and raspberry juices", Food Resource International, Vol. 30, pp. 811-817, 1998.

[119]. F. Voragen, H. Schols, R. Visser, "Advances in pectin and pectinase research", Annals of Botany, Vol. 94, pp. 479-480, 2003.

[120]. J. Weiss and H. Samann, "Turbidity stability of apricot nectar", Mitt Rebe Wein Obstbau Fruchteverwert, Vol. 22, pp. 177-184, 1972.

[121]. J.R. Whitaker, "Pectic substances, pectic enzymes and haze formation in fruit juices", Enzyme Microbial Technology, Vol. 6, pp. 341-349, 1984. 